\title{
STRATEGI SALURAN DISTRIBUSI OBAT TRADISIONAL PADA PT KARYA PAK OLES TOKCER
}

\author{
Erina Diah Nur'aini ${ }^{1}$, Sri Wahyuni ${ }^{1}$, Joko Widodo ${ }^{1}$ \\ ${ }^{1}$ Pendidikan Ekonomi, Fakultas Keguruan dan Ilmu Pendidikan, Universitas Jember \\ Jln. Kalimantan 37, Jember 68121 \\ E-mail: erinadiahnuraini@gmail.com
}

\begin{abstract}
Abstrak
Penelitian ini bertujuan untuk mendeskripsikan strategi saluran distribusi yang diterapkan pada PT Karya Pak Oles Tokcer. Penelitian ini merupakan penelitian deskriptif dengan pendekatan kualitatif. Subjek dan informan penelitian yaitu kepala cabang Jember, kepala unit Probolinggo, Team Leader (TL), SPG dan penjaga counter. Metode pengumpulan data yang digunakan yaitu wawancara dan dokumen. Metode analisis data yang digunakan yaitu tahap reduksi data, penyajian data dan penarikan kesimpulan. Hasil penelitian menunjukan bahwa dalam menentukan strategi saluran distribusi perusahaan harus mempertimbangkan beberapa faktor diantaranya pasar, produk, perantara, dan perusahaan. Sehingga dapat diketahui strategi saluran distribusi intensiflah yang diterapkan oleh PT Karya Pak Oles Tokcer dengan menggunakan saluran distribusi tidak langsung yang terdiri dari satu tingkat perantara yaitu pengecer. Pengecer yang digunakan yaitu Sales Promotion Group (SPG), counter penjualan dan apotik. Pengecer tersebut dipilih perusahaan untuk mendistribusikan produk hingga ke konsumen akhir. Strategi yang digunakan oleh PT Karya Pak Oles Tokcer untuk apotik yaitu dengan memberikan potongan harga sebesar $20 \%$, sehingga produk yang terjual kepada konsumen akhir sama
\end{abstract}

Kata Kunci: Strategi Saluran Distribusi

\section{PENDAHULUAN}

Pemasaran memiliki peranan penting dalam meningkatkan kelangsungan hidup perusahaan melalui perluasan pasar hingga ke luar daerah produksinya. Sehingga strategi saluran distribusi harus tepat agar tidak terjadi keterlambatan pengiriman produk kepada konsumen akhir. Perusahaan juga harus mempertimbangkan beberapa faktor dalam menentukan strategi saluran distribusi yang tepat diantaranya pertimbangan pasar, produk, perantara, dan perusahaan. Saluran distribusi ini memegang peranan penting bagi perusahaan yaitu dapat memperluas daerah pemasaran. Strategi saluran distribusi merupakan manajemen saluran distribusi yang digunakan oleh produsen untuk memasarkan produknya sehingga sampai ke tangan konsumen akhir (Tjiptono, 2002:205). Perusahaan harus jeli dalam menentukan strategi saluran distribusi mana yang akan digunakan karena apabila terjadi kesalahan dalam pemilihan strategi saluran distribusi maka akan mengganggu proses penyaluran produk kepada konsumen akhir

Saat ini tanaman obat tradisional semakin berkembang di Indonesia lebih dari 30.000 spesies tanaman obat yang sudah tumbuh tapi baru 9.600 spesies saja yang memiliki khasiat obat dan 200 spesies yang dimanfaatkan untuk pengobatan tradisioanal. Kini dengan adanya kemajuan zaman tanaman obat sudah diolah menjadi obat tradisional yang mudah didapat dan satu produk praktis bisa meringankan berbagai macam penyakit. Sehingga bermunculan Industri Obat Tradisional yang biasa disingkat IOT. Salah satu perusahaan yang melakukan pendistribusian produk obat tradisional yang tetap eksis hingga 21 tahun lamanya yaitu PT Karya Pak Oles Tokcer. Perusahaan ini memiliki kantor pusat dan pabrik di Bali. Produk obat tradisional ini sudah dikenal oleh konsumen lokal hingga mancanegara serta mendapatkan respon positif mengenai manfaat yang diberikan oleh obat tradisional tersebut. Produk yang 
dihasilkan sebanyak 45 produk dan Minyak Oles Bokashi menjadi idola dan banyak dicari oleh konsumen.

Berdasarkan penjelasan diatas, terdapat batasan penelitian yang dilakukan pada PT Karya Pak Oles Tokcer yaitu pada cabang Jember dengan pertimbangan bahwa kepala cabang Jember mampu memberikan data dan informasi mengenai strategi saluran distribusi obat tradisional. Penelitian ini bertujuan untuk mendeskripsikan strategi saluran distribusi yang diterapkan pada obat tradisional PT Karya Pak Oles Tokcer.

\section{METODE}

Penelitian ini merupakan penelitian deskriptif dengan pendekatan kualitatif. Penentuan lokasi yaitu pada PT Karya Pak Oles Tokcer sedangkan penentuan subjek dan informan penelitian yaitu kepala cabang Jember PT Karya Pak Oles Tokcer, kepala unit Probolinggo, Team Leader (TL), Sales Promotion Group (SPG), penjaga counter, pengecer apotik. Metode pengumpulan data yang digunakan terdiri dari metode wawancara dan metode dokumen. Metode analisis data yang digunakan dalam penelitian ini yaitu tahap reduksi data, tahap penyajian data dan penarikan kesimpulan.

\section{HASIL DAN PEMBAHASAN \\ Hasil Penelitian}

Berdasarkan data yang diperoleh dapat diketahui bahwa PT Karya Pak Oles Tokcer merupakan perusahaan yang bergerak di bidang industri obat tradisional yang didirikan oleh Dr. Ir. Gede Ngurah Wididana, M. Agr sejak tahun 1997. Proses produksi obat tradisional ini dengan membudidayakan sendiri tanaman obat hingga mengekstraksi menggunakan teknologi EM (Effective Microorganism) dan sudah mendapatkan sertifikat CPOTB (Cara Pembuatan Obat Tradisional yang Baik dan Benar) pada tahun 2012. Sebagai produsen obat tradisional, produk ini sudah terdaftar di BPOM. PT Karya Pak Oles Tokcer memiliki 63 unit kantor pemasaran yang tersebar di Indonesia. Salah satunya di kota Jember yang berlokasi di Jalan Kalimantan Ruko 34 Kavling 6, Sumbersari. Hasil penelitian bahwa PT Karya Pak Oles Tokcer menggunakan strategi saluran distribusi intensif yang terdiri dari saluran distribusi tidak langsung berdasarkan beberapa pertimbangan yaitu pasar, produk, perantara dan perusahaan.

\section{Pertimbangan Pasar}

Pemilihan saluran distribusi berdasarkan jenis pasar PT Karya Pak Oles Tokcer berbentuk Industri namun termasuk ke dalam jenis pasar konsumen karena obat-obatan merupakan kebutuhan yang harus terpenuhi dan menjadi kebutuhan pokok apabila konsumen tersebut dalam keadaan sakit. Pelanggan potensial yang sering melakukan pembelian untuk cabang Jember saja mencapai 200 orang/bulan belum cabang yang lainnya. Konsentrasi geografi pasar yang ingin dicapai yaitu untuk penduduk kota bisa membeli produk melalui counter penjualan yang telah tersebar di seluruh Indonesia sedangkan untuk penduduk desa perusahaan menerjunkan SPGnya. Pertimbangan selanjutnya yaitu jumlah dan ukuran pesanan dimana untuk pesanan yang banyak maka gudang pusat akan secara langsung mendistribusikan produknya kepada kantor pemasaran ataupun apotik.

\section{Pertimbangan Produk}

Harga produk obat tradisional yang dihasilkan PT Karya Pak Oles Tokcer bervariasi dari harga Rp. 10.000 - Rp. 160.000. Produk obat tradisional ini tergolong ke dalam produk yang memiliki daya tahan lama dengan masa kadaluarsa selama 2 tahun. Perusahaan juga memberikan sifat teknis produk berupa penjelasan lebih mendalam mengenai cara pemakaian produk dan manfaat produk tersebut. 


\section{Pertimbangan Perantara}

PT Karya Pak Oles Tokcer dalam memasarkan produk menggunakan beberapa perantara yaitu kantor cabang pemasaran, kantor unit pemasaran, Team Leader (TL), Sales Promotion Group (SPG) dan apotik. Jika perantara tersebut bekerja dengan baik maka perusahaan akan menggunakan jasanya dan memberikan balas jasa yang sesuai. Bagi perantara karyawannya perusahaan memberikan balas jasa berupa insentif yang dimasukan ke dalam gaji. Bagi perantara apotik perusahaan memberikan komisi sebesar 20\% setiap produk. Perusahaan akan membuat kebijakan baru apabila kebijakan di awal dirasa banyak hambatan. Terkadang kebijakan baru tersebut sulit diterima oleh perantaranya, maka perusahaan harus mempertimbangkan lagi akan menggunakan perantara tersebut atau tidak.

\section{Pertimbangan Perusahaan}

PT Karya Pak Oles Tokcer memiliki kantor pemasaran yang tersebar di Indonesia sejumlah 63 unit. Hal ini membuktikan bahwa perusahaan ini memiliki permodalan yang kuat. Perusahaan juga melakukan kontroling seminggu sekali dan audit sebulan sekali agar tidak terjadi penyelewengan dalam mendistribusikan produk kepada konsumen akhir. Jika perusahaan mampu mengendalikan saluran distribusinya maka perusahaan bisa melakukan promosi yang agresif melalui periklanan maupun mendatangi instansi.

\section{Strategi Saluran Distribusi Obat Tradisional Pada PT Karya Pak Oles Tokcer}

Perusahaan ini menggunakan strategi saluran distribusi intensif pada saluran distribusi tidak langsung. Saluran distribusi tidak langsung merupakan pendistribusian produk dari produsen hingga ke konsumen akhir dengan menggunakan beberapa perantara. Berikut ini bentuk saluran distribusi yang dilakukan PT Karya Pak Oles Tokcer.

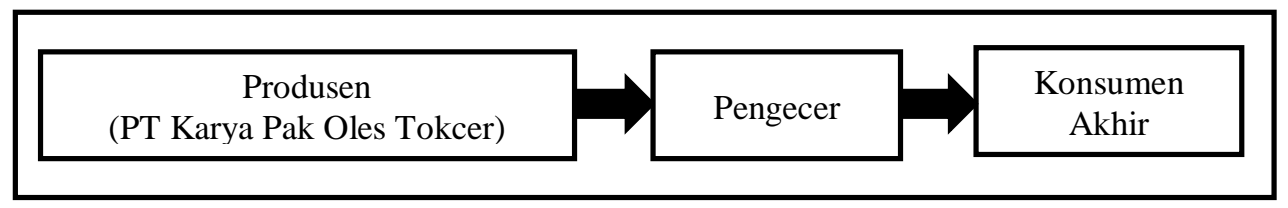

Gambar 1. Bentuk Saluran Distribusi Tidak Langsung PT Karya Pak Oles Tokcer

Gambar diatas menunjukkan bahwa perusahaan menggunakan satu perantara dalam mendistribusikan produk yaitu pengecer. Pengecer yang digunakan oleh PT Karya Pak Oles Tokcer yaitu Sales Promotion Group (SPG), counter penjualan dan apotik.

Saluran distribusi tidak langsung produk dimulai dari produsen yang telah mengelola tanaman obat menjadi obat tradisional. Produk yang telah di produksi segera disimpan di gudang pusat yang berada di Bali. Setelah itu karyawan gudang pusat mengirimkan produk tersebut kepada kantor cabang pemasaran untuk dimasukan ke gudang cabang dan menambah stok produk di counter penjualan cabang. Kemudian gudang cabang menyalurkan produk kepada setiap kantor unit pemasaran yang ada dibawah naungannya. Pendistribusian produk ini dilakukan sendiri oleh kepala unitnya seminggu sekali. Setelah produk berada di kantor unit pemasaran maka kepala unit mendistribusikan produknya kepada Sales Promotion Group (SPG) dan counter penjualan unit untuk menjualnya kepada konsumen akhir.

Pengiriman produk yang dilakukan oleh produsen kepada kantor cabang pemasaran yaitu sebulan sekali tepatnya pada awal bulan dengan menggunakan alat transportasi truk sedangkan pengiriman produk dari kantor cabang pemasaran kepada kantor unit pemasaran dilakukan seminggu sekali oleh kepala unitnya langsung menggunakan mobil atau sepeda motor. Namun jika ada pesanan yang mendesak maka perusahaan akan melayaninya dengan menggunakan ekspedisi Dakota. Perusahaan lebih mengutamakan penggunaan SPG (Sales Promotion Group) dalam mencari konsumen melalui instansi hingga ke pelosok desa sehingga dapat memasarkan produk dalam jumlah besar dan skala yang lebih luas, Namun tidak semua orang bisa menjadi SPG karena perusahaan sangat selektif serta memiliki kriteria tertentu diantaranya mempunyai dedikasi yang tinggi, bekerja keras, ulet, jujur dan bisa mengelola stok. 
PT Karya Pak Oles Tokcer juga mendirikan counter penjualan di setiap kantor cabang pemasaran dan kantor unit pemasaran yang tersebar di Indonesia meliputi DKI Jakarta, Jawa Barat, Yogyakarta, Jawa Tengah, Jawa Timur, NTB, Sulawesi Selatan dan terdapat juga counter penjualan di Bokashi Farm. Bokashi Farm merupakan kebun herbal yang dikelola oleh pemilik PT Karya Pak Oles Tokcer yaitu Dr. Ir. Gede Ngurah Wididana, M. Agr. Melalui kebun herbal ini banyak wisatawan lokal hingga wisatawan asing yang berkunjung dan membeli produk obat tradisional ini, sehingga perusahaan ini sudah mampu melakukan ekspor ke Jepang dan Korea. Bokashi Farm ini berlokasi di Jalan Waribang No. 27 Kesiman-Denpasar. Perusahaan juga menawarkan produk melalui sosial media seperti Website, Instagram, Facebook, dan WhatsApp.

PT Karya Pak Oles Tokcer juga mendistribusikan produknya melalui apotik yang tersebar di Jawa dan Bali. Banyaknya pengecer apotik yang mendistribusikan produk maka perusahaan menunjuk SPGnya untuk mendistribusikan produk yang telah dipesan oleh apotik dengan menggunakan alat transportasi mobil atau motor karena letak lokasi yang dekat dengan tempat produksi ataupun kantor pemasarannya. Pengiriman produk dilakukan dua bulan sekali. Produk yang dijual oleh apotik hanya Minyak Oles Bokashi dan aneka madu. Sistim pembayaran yang dilakukan yaitu tunai setelah pemesanan dan langsung melakukan pembayaran kepada SPG. Strategi yang digunakan untuk apotik yaitu berupa potongan harga 20\% sehingga harga kepada konsumen akhir sama, Adapun beberapa pengecer apotik PT Karya Pak Oles Tokcer yang ada dibawah naungan cabang Jember:

Tabel 1. Data Pengecer Apotik dan Outlet PT Karya Pak Oles Tokcer di Jember

\begin{tabular}{ccl}
\hline No & \multicolumn{1}{c}{ Kota } & \multicolumn{1}{c}{ Nama Pengecer } \\
\hline 1 & Jember & $\begin{array}{l}\text { Apotik Waluyo Gung, Radio Suara Akbar, Apotik Abiath, } \\
\text { Apotik Tanggul Sehat, Apotik Mulya Farma }\end{array}$ \\
\hline 2 & Lumajang & $\begin{array}{l}\text { Apotik Madani, Apotik Kondang Waras, An-Nur Madu dan } \\
\text { Herbal, Apotek Labruk Sehat, Apotik Miranti Farma, Apotik } \\
\text { Asiska. }\end{array}$ \\
\hline 3 & Probolinggo & $\begin{array}{l}\text { Apotik Sarinah Farma, Suropati Apotik, Toko Jamu 52 } \\
\text { Pahlawan, Apotik Fajar, Apotik Shelomita, Apotik Kurnia } \\
\text { Farma }\end{array}$ \\
\hline 4 & Banyuwangi & $\begin{array}{l}\text { Apotik Ima, Apotik Prima, Apotik Kasih Farma, Apotik } \\
\text { Cinta Sehat, Blambangan Apotik, Apotik Saelendra }\end{array}$ \\
\hline 5 & Bondowoso & $\begin{array}{l}\text { Apotik Pudja Farma, Apotik Sinar Sejati, Apotik Cendana } \\
\text { Raya, Apotek Sahabat, Apotik Sido Mulyo, Apotik } \\
\text { Muazara. }\end{array}$ \\
\hline 6 & Situbondo & $\begin{array}{l}\text { Apotik Cendrawasih, Apotik Sumber Sehat, Apotik } \\
\text { Andromeda, Apotek Dadi Sehat, Apotik Jaya Sehat, Apotek } \\
\text { Asembagus }\end{array}$ \\
\hline
\end{tabular}

Data : Bapak I Made Suwije selaku kepala cabang Jember, 2019

Tabel diatas menunjukan data pengecer apotik yang dimiliki PT Karya Pak Oles Tokcer yang sudah tersebar di Jember, Lumajang, Probolinggo, Bondowoso, Situbondo, dan Banyuwangi. Hal ini menunjukkan bahwa produk obat tradisional milik PT Karya Pak Oles Tokcer sudah dijual di Apotik yang berada dibawah naungan kantor cabang Jember.

Berdasarkan pendistribusian produk yang dilakukan oleh PT Karya Pak Oles Tokcer menggunakan strategi saluran distribusi intensif yang bertujuan memenuhi kebutuhan konsumen terhadap obat tradisional di berbagai lokasi dengan menggunakan perantara SPG, counter penjualan dan apotik Penerapan strategi saluran distribusi intensif ini tepat karena harganya yang terjangkau bagi konsumen akhir yaitu dari harga Rp. 10.000 hingga Rp. 160.000 serta 
harga yang diberikan perusahaan untuk konsumen akhir sama. Penerapan strategi saluran distribusi intensif ini memiliki kekuatan dan kelemahan. Kekuatan dalam menerapkan strategi saluran distribusi ini memudahkan konsumen akhir untuk mendapatkan produk karena mereka tidak perlu datang langusng ke tempat produksinya. Kelemahan strategi saluran distribusi intensif ini yaitu cukup sulit untuk mengendalikan pengecer dalam jumlah banyak yang telah tersebar di Jawa dan Bali. Sehingga pengawasan terhadap apotik berkurang. Kesulitan ini juga disebabkan apotik yang menjual berbagai jenis obat dari produsen lain. Pengecer juga tidak mengutamakan promosi karena produk ini sudah banyak dikenal dan sudah laris manis.

\section{Pembahasan}

Pembahasan pada peneltian ini bertujuan untuk menjelaskan hasil penelitian yang dilakukan pada PT Karya Pak Oles Tokcer ditinjau dari segi strategi saluran distribusi yang digunakan yaitu strategi saluran distribusi intensif yang meliputi saluran distribusi tidak langsung. Pendistribusian produk kepada konsumen akhir menggunakan saluran distribusi intensif melalui counter penjualan yang tersebar di seluruh Indonesia serta apotik yang tersebar di Jawa dan Bali, bahkan perusahaan juga memperbanyak jumlah SPG sehingga produk ini bisa dikenal oleh masyarakat luas. Hal ini sesuai dengan pendapat Kotler dan Keller (2009:118) bahwa perusahaan yang menempatkan produknya di banyak gerai ritel merupakan strategi saluran distribusi intensif.

Saluran distribusi tidak langsung ini menggunakan bantuan perantara untuk mendistribusikan produknya. Saluran distribusi tidak langsung yang diterapkan meliputi produsen - pengecer - konsumen akhir. Perantara yang digunakan yaitu pengecer dimana penggunaan satu perantara termasuk kedalam saluran distribusi tingkat pertama. Hal ini sesuai dengan pendapat Sumarwan (2015:102) pada saluran distribusi tingkat pertama ini pengecer menjadi perantaranya. Pengecer yang digunakan PT Karya Pak Oles Tokcer yaitu SPG untuk menjual produk kepada konsumen akhir secara ecer. Pendistribusian produk ini melalui instansi atau mencari konsumen hingga ke pelosok desa. Perusahaan juga membuka counter penjualan di setiap kantor cabang maupun kantor unit pemasaran serta di kebun herbal Bokashi Farm dimana memudahkan konsumen jika ingin datang langsung untuk membeli produk. Perusahaan juga menawarkan produk melalui sosial media seperti Website, Facebook, Instagram, WhatsApp dengan menggunakan bantuan jasa pengiriman Kantor Pos, JNT, JNE dan biaya ongkos kirim dibebankan kepada konsumen.

Pendistribusian produk kepada konsumen akhir juga dilakukan oleh apotik yang telah tersebar di Pulau Jawa dan Bali. Perusahan memberikan potongan harga20\% sehingga harga yang dijual kepada konsumen akhir sama. Saluran distribusi tidak langsung ini PT Karya Pak Oles Tokcer merasa diuntungkan karena dapat mengetahui pendapat konsumen dari pengecer apotik. Hal ini sesuai dengan pendapat Manap (2016:200) melalui pengecer produsen dapat memperoleh data mengenai pandangan konsumen terhadap produk yang telah dihasilkan.

Strategi saluran distribusi intensif yang digunakan oleh memiliki kekuatan dan kelemahan. Kekuatan yang didapat yaitu bisa meningkatkan penjualan dan memudahkan konsumen akhir untuk mendapatkan produk obat tradisional ini dengan menggunakan saluran distribusi tidak langsung. Sehingga memberikan kenyamanan terhadap konsumen untuk memperoleh produk ini di berbagai lokasi tanpa datang langsung ke tempat produksinya. Hal ini juga disampaikan oleh Sumarwan (2015:109) bahwa strategi saluran distribusi intensif dapat meningkatkan penjualan dan ketersediaan produk di area seluas mungkin.

Kelemahan dalam menerapkan strategi saluran distribusi intensif yaitu kesulitan dalam mengendalikan pengecer apotik karena sudah tersebar luas, sehingga pengawasan terhadap apotik berkurang. Hal ini sesuai dengan pendapat Tjiptono (2002:209) bahwa resiko pelaksanaan strategi saluran distribusi intensif yaitu sulit mengendalikan gerai ritel yang ada, sehingga perantara juga menjual produk dari produsen lain. Penggunaan strategi saluran distribusi intensif ini menyebabkan pengecer tidak mengutamakan promosi karena produk obat 
tradisional ini sudah dikenal dan laris terjual. Hal ini sesuai dengan pendapat Tjiptono (2002:209) bahwa komitmen pengecer untuk melakukan promosi relatif rendah.

\section{PENUTUP}

Berdasarkan hasil penelitian dan pembahasan yang telah dipaparkan dapat disimpulkan bahwa PT Karya Pak Oles Tokcer menggunakan strategi saluran distribusi intensif. Pelaksanaan strategi saluran distribusi intensif menggunakan saluran distribusi tidak langsung yang terdiri dari satu perantara meliputi produsen - pengecer - konsumen akhir. Pengecer yang digunakan oleh perusahaan yaitu Sales Promotion Group (SPG). Perusahaan juga mendirikan counter penjualan yang berada di setiap kantor cabang pemasaran dan kantor unit pemasaran bukan hanya di Bali dan daerah sekitarnya, melainkan pendirian counter penjualan sudah tersebar di seluruh Indonesia termasuk counter penjualan yang berada di kebun herbal Bokashi Farm. PT Karya Pak Oles Tokcer juga mendistribusikan produknya kepada apotik yang telah tersebar di Jawa dan Bali sehingga memberikan kemudahan bagi para konsumennya. Strategi yang digunakan oleh perusahaan untuk setiap apotik yaitu berupa potongan harga sebesar $20 \%$. Sehingga produk yang terjual kepada konsumen akhir sama.

Berdasarkan hasil penelitian, maka peneliti menyarankan sebaiknya PT Karya Pak Oles Tokcer lebih meningkatkan jumlah pengecer apotik khususnya diluar daerah Jawa dan Bali agar konsumen lebih mudah mendapatakan produk obat tradisional dari PT Karya Pak Oles Tokcer.

\section{DAFTAR PUSTAKA}

Afrizal. 2015. Metode Penelitian Kualitatif. Depok: PT Rajagarfindo Persada

Bungin, B. 2013. Metodologi Penelitian Sosial dan Ekonomi. Jakarta: Kencana Prenada Media Group

Kotler, P dan G. Armstrong. 2008. Prinsip-Prinsip Pemasaran. Jakarta: Erlangga

Kotler, P dan K. L. Keller. 2009. Manajemen Pemasaran Jilid 2. Jakarta: Erlangga

Manap, A. 2016. Resolusi Manajemen Pemasaran. Jakarta: Mitra Wacana Media

Sumarwan, U. dkk. 2015. Pemasaran Strategik-Perspektif Perilaku Konsumen dan Marketing Plan. Bogor: IPB Press

Tjiptono, F. 2002. Strategik Pemasaran. Yogyakarta: ANDI

\section{Internet}

Profil PT Karya Pak Oles Tokcer. https://pakoles.com/index.php/profil/1/PT-Karya-Pak-OlesTokcer.html. [Diakses 3 Oktober 2018]

Umardini, T. 2018. 30.000 Spesies Tanaman Obat Herbal Ada Di Indonesia Tapi Ini Yang Disayangkan. http://kaltim.tribunnews.com/2018/05/07/30000-spesies-tanaman-obatherbal-ada-di-indonesia-tapi-ini-yang-disayangkan. [Diakses 29 Desember 2018] 